\title{
ALTERNATIVE SUBSTRATES IN DIFFERENT CONTAINERS FOR PRODUCTION OF CONILON COFFEE SEEDLINGS
}

\author{
Mário Euclides Pechara da Costa Jaeggi ${ }^{1}$, Julio Cesar Gradice Saluci², Rogério Rangel Rodrigues ${ }^{3}$, \\ Geraldo de Amaral Gravina ${ }^{4}$, Wallace Luis de Lima ${ }^{5}$
}

(Received: January 23, 2017; accepted: Tuesday, May 2, 2017)

\begin{abstract}
Different substrates and containers influence the production of coffee seedlings, which can reduce production costs, both with alternative substrates and with containers of smaller volumes of substrates. The aim the present study was to evaluate the viability of alternative substrates in different containers for production of Conilon coffee (Coffea canephora Pierre ex Froehner) seedlings in the nursery of the Federal Institute of Espírito Santo - Campus of Alegre, ES, Brazil. The experimental design was a randomized complete block design with three replications, in split-plot with three plots and four subplots. The plots consisted of three containers $\left(120 \mathrm{~cm}^{3}\right.$ tube, $280 \mathrm{~cm}^{3}$ tube and $615 \mathrm{~cm}^{3} \mathrm{bag}$ ), and the subplots of four substrates (S1 - Conventional, S2 - Legume compost, S3 - Grass compost, S4 - Vermicompost). At 165 days after sowing, the evaluated variables were shoot and root dry mass, number of leaves, shoot height, leaf area, Dickson quality index, shoot/root ratio, root length, nitrogen and total crude protein. The alternative substrates (Legume compost, Grass compost and Vermicompost) were efficient for production of Conilon coffee seedlings and can replace the conventional substrate at this development stage, providing good quality seedlings. The major developments were observed in the containers with the highest volume $\left(280 \mathrm{~cm}^{3}\right.$ tube and $615 \mathrm{~cm}^{3} \mathrm{bag}$ ) and reflected directly on the quality of seedlings.
\end{abstract}

Index terms: Coffea canephora, development, alternative compost.

\section{SUBSTRATOS ALTERNATIVOS EM DIFERENTES RECIPIENTES NA PRODUÇÃO DE MUDAS DO CAFEEIRO CONILON}

RESUMO: Diferentes substratos e recipientes influenciam a produção de mudas de cafeeiro, podendo reduzir custos de produção, tanto com substratos alternativos quanto com recipientes de menores volumes de substratos. Objetivando avaliar a viabilidade de substratos alternativos em diferentes recipientes na produção de mudas do cafeeiro conilon (Coffea canephora Pierre ex Froehner), realizou-se o presente trabalho no viveiro do Instituto Federal do Espírito Santo - Campus de Alegre. O delineamento experimental utilizado foi em blocos casualizados, com 3 repetições, em parcela subdividida, com 3 parcelas e 4 subparcelas. As parcelas foram constituídas por 3 recipientes (tubete de $120 \mathrm{~cm}^{3}$, tubete de $280 \mathrm{~cm}^{3}$ e sacola de 615 $\mathrm{cm}^{3}$ ), e as subparcelas por 4 substratos (S1 - Convencional; S2 - Composto de leguminosa; S3 - Composto de gramínea; S4 - Vermicomposto). Aos 165 dias após a semeadura as variáveis avaliadas foram: massa seca da parte aérea e raiz, número de folhas, altura da parte aérea, área foliar, índice de qualidade de Dickson, relação parte aérea/raiz, comprimento da raiz, nitrogênio e proteína bruta total. Os substratos alternativos (Composto de leguminosa; Composto de gramínea e Vermicomposto) foram eficientes na produção de mudas de cafeeiro conilon e podem substituir o substrato convencional nesta fase do desenvolvimento, proporcionando mudas de boa qualidade. Os maiores desenvolvimentos foram observados nos recipientes de maior volume (tubete de $280 \mathrm{~cm}^{3}$ e sacola de $615 \mathrm{~cm}^{3}$ ) e refletiram diretamente na qualidade das mudas.

Termo para indexação: Coffea canephora, desenvolvimento, composto alternativo.

\section{INTRODUCTION}

The quality of seedling is linked directly to the productivity and quality of the final product (TRAZZI et al., 2013). For the Brazilian coffee growing, the quality of Conilon coffee (Coffea canephora Pierre ex Froehner) seedling is extremely important, since it undergoes major transformations such as the increasing planted area, renewal of the coffee plantation and adaptation to the current planting systems. Thereby, the planting of vigorous coffee seedlings is fundamental for a good setting, reducing the expenses with the replanting operation and contributing to the rapid initial growth of seedlings in the field (ALVES; GUIMARÃES, 2010; CARVALHO et al., 2008).

The technology of coffee seedling production has been changed with research to determine the type of container, substrate, time and management of the fertilization and irrigation ideal for its quality production (HENRIQUE et al., 2011). The most commonly used containers are

\footnotetext{
${ }^{1}$ Rua Bernardo Vargas, nº73 - Rive - 29.520-000 - Alegre - ES - mariopechara@hotmail.com

${ }^{2}$ Rua Bernardo Vargas, $n^{\circ}$ s/n - Rive - 29.520-000 - Alegre - juliosaluci@gmail.com

${ }^{3}$ Rua Isaias Gomes de Oliveira, ${ }^{\circ}$ 238, apt ${ }^{\circ} 201$ - Bairro Jardim Fabiana - 37.200-000 -Lavras - MG - rogeriorr7@hotmail.com ${ }^{4}$ State University Norte Fluminense Darcy Ribeiro - Avenida Alberto Lamego, n 2000 - Parque Califórnia - 28.013-602 Campos dos Goytacazes - RJ - gravina@uenf.br

${ }_{5}^{5}$ Federal Institute of Education - Science and Technology of Espírito Santo - Campus de Alegre - Rua Principal, n ${ }^{\circ}$ s/n - Rive Cx. P. 47 - 29.520-000 - Alegre - ES - wallace@ifes.edu.br
} 
plastic bags filled with substrate formed by soil and cow dung (7:3 ratio) and polyethylene tubes with different dimensions, using a commercial substrate (VALLONE et al., 2010; VALLONE; GUIMARÃES; MENDES, 2010).

For container types and volumes, Silva et al. (2010) and Vallone, Guimarães and Mendes (2010) sought to define an ideal set, associating quality with reduced production cost providing a better development to the coffee plants. According to Silva et al. (2010), soil block ( $60 \times 40 \times 15 \mathrm{~cm})$, polyethylene bag $(18 \mathrm{~cm}$ height $\mathrm{x} 10 \mathrm{~cm}$ diameter) and large tube $(120 \mathrm{ml})$ are the most suitable containers for the production of $C$. canephora seedlings.

Regarding the substrate, Vallone, Guimarães and Mendes (2010) reported that the mixture of organic wastes to the substrate improves their chemical, physical and biological characteristics, providing an adequate environment for roots and plant as a whole, notably in its initial development, reducing the soil usage and hence avoiding the contamination risks by pests and diseases. Thus, the substrates should have good characteristics such as adequate porosity, high cation exchange capacity, good water retention, and must be produced in a sustainable way with economic viability (ALMEIDA et al., 2011).

It is necessary the use plant and animal residues in the preparation of substrates for the production of agricultural seedlings, besides giving adequate destination to them. According to Caldeira et al. (2008), organic matter is one of the fundamental constituents of substrates, whose basic purpose is to increase the water retention capacity and availability of nutrients to the seedlings.

Based on the usage relevance of alternative residues for the production of agricultural seedlings and the effect of the container on the production of seedlings, the present study aimed to evaluate the effects of alternative substrates in different containers for production of Conilon coffee seedlings.

\section{MATERIAL AND METHODS}

The experiment was carried out at the Federal Institute of Espírito Santo (IFES) Campus of Alegre, in the city of Alegre, ES, Brazil, in a seedling nursery built with bamboo structure and covered with $50 \%$ shade net. The nursery has as geographic coordinates $20^{\circ} 45^{\prime} 44^{\prime \prime}$ $\mathrm{S}, 41^{\circ} 27^{\prime} 43^{\prime} \mathrm{W}$, and $134 \mathrm{~m}$ altitude. According to
Köppen classification, the climate of the region is "Aw" type, dry winter and rainy summer with annual average temperature of $23{ }^{\circ} \mathrm{C}$ and annual rainfall around $1,200 \mathrm{~mm}$. The rainy season in the region is concentrated from November to March.

The experimental design was a randomized complete block design with three replications, in split-plot with three plots and four subplots. The plots consisted of three containers $\left(120 \mathrm{~cm}^{3}\right.$ tube, $280 \mathrm{~cm}^{3}$ tube and $615 \mathrm{~cm}^{3}$ polyethylene bag), and the subplots of four substrates (S1 - Conventional, $\mathrm{S} 2$ - Legume + dried cow dung compost, S3 - Grass + cow dung compost, S4 - Vermicompost). The used containers have the primary characteristic of non-releasing toxins in the culture substrate. The experimental plot consisted of 20 plants, being used the average of three plants, discarding the edge.

The used substrates were: S1 - Conventional - made with ravine land with cow dung at 3:1 ratio $(\mathrm{v} / \mathrm{v})$ added with N-P-K fertilization recommended for the crop (PREZOTTI et al., 2007); S2 Organic compost of legume, constituted based on legume (pigeon pea) with cow dung at of 1:1 ratio $(\mathrm{v} / \mathrm{v})$ after the maturation process of the material reaching 90 days; S3 - Organic compost of grass derived from the compost process of cow dung and grass clippings at 1:1 ratio $(\mathrm{v} / \mathrm{v})$, as described by Souza et al. (2013); and S4 - Vermicompost, prepared after the maturation process of the organic compost (grass and dried cow dung), using redworms (Eisenia foetida) throughout 60 days for the vermicompost process.

The substrates were characterized through a chemical analysis in the Soil Fertility Laboratory of the Department of Soils of the Federal Rural University of Rio de Janeiro, RJ, Brazil (Table 1). The "EMCAPER 8151 - Robusta Tropical" cultivar was evaluated. Two seeds were used per container, sowed at $1.0 \mathrm{~cm}$ depth. The thinning was performed soon after the first pair of true leaves emerged, removing the less vigorous plants (MATTIELO et al., 2005).

Irrigations were performed twice a day (morning and afternoon) by micro-sprinkling until the end of the experimental phase. At 165 days after sowing, the evaluated characteristics were shoot and root dry mass $\left(\mathrm{g} \mathrm{plant}^{-1}\right)$, number of leaves, shoot height $\left(\mathrm{cm}\right.$ plant $\left.{ }^{-1}\right)$, leaf area $\left(\mathrm{cm}^{2}\right.$ plant $^{-1}$ ), Dickson quality index, shoot/root ratio, root length $\left(\mathrm{cm}\right.$ plant $\left.t^{-1}\right)$, total nitrogen $\left(\%\right.$ plant $\left.^{-1}\right)$ and total crude protein $\left(\%\right.$ plant $\left.^{-1}\right)$. Root length was measured with graduated scale, measuring the pivoting root. 
TABLE 1 - Chemical characterization of substrates used for production of Conilon coffee seedlings

\begin{tabular}{|c|c|c|c|c|c|c|c|}
\hline Substrates & $\mathrm{N}$ & $\mathrm{P}_{2} \mathrm{O}_{5}$ & $\mathrm{~K}_{2} \mathrm{O}$ & $\mathrm{Mg}$ & $\mathrm{Ca}$ & $\mathrm{C}$ & $\begin{array}{l}\mathrm{pH} \text { in } \\
\text { water }\end{array}$ \\
\hline & \multicolumn{3}{|c|}{$\mathrm{mg} \mathrm{dm}{ }^{-3}$} & \multicolumn{2}{|c|}{$\mathrm{cmol}_{\mathrm{c}} \mathrm{dm}^{-3}$} & $\mathrm{~g} \mathrm{~kg}^{-1}$ & \\
\hline $\mathrm{S} 1$ & 18 & 38 & 18.07 & 5 & 26 & 40.7 & 6.2 \\
\hline $\mathrm{S} 2$ & 33 & 28.1 & 15.36 & 5.7 & 2.9 & 158 & 8.8 \\
\hline $\mathrm{S} 3$ & 15 & 16 & 30.6 & 5.3 & 27.9 & 62 & 7.4 \\
\hline S4 & 15 & 36.3 & 36.72 & 7.9 & 5.3 & 113 & 6.7 \\
\hline
\end{tabular}

S1 - Conventional; S2 - Legume + dried cow dung compost; S3 - Grass + dried cow dung compost; S4 Vermicompost.

The shoot and root dry mass were obtained in digital scale after drying in a convection oven at $75{ }^{\circ} \mathrm{C}$ until constant weight. The height was measured with a millimeter ruler, considering the region between the collar and the apical bud.

Leaf area (LA) was measured by the mathematical model $A F=0,2027 C N C^{2,1336}$ $A F=0,2027 C N C^{2,1336}$ (PARTELLI et al., 2006), where ML is the midrib length.

The Dickson quality index was obtained by the formula: DQI = [total dry mass / (height/ diameter ratio + shoot/root ratio)] recommended by Dickson, Leaf and Hosner (1960).

The total nitrogen was obtained by the Kjeldahl method based on the decomposition of organic matter by digesting the sample at $400{ }^{\circ} \mathrm{C}$ with concentrated sulfuric acid in the presence of copper sulphate as a catalyst that accelerates the oxidation of organic matter. The nitrogen present in the resulting acid solution was determined by steam distillation followed by titration with diluted acid (NOGUEIRA; SOUZA, 2005).

The protein content of a food is measured from the nitrogen content present in the analyzed sample. The analysis is performed by the Kjeldahl method and the obtained nitrogen percentage is multiplied by 6.25 and then expressed as crude protein $(\mathrm{CP})$. This analysis is because all proteins have $16 \%$ nitrogen, and that all nitrogen in the food is in protein form (NOGUEIRA; SOUZA, 2005).

The expression $\left(\mathrm{TCP}=\mathrm{TN}_{\mathrm{x} \mathrm{F}}\right)$ was used to determine the total crude protein (TCP), where $\mathrm{TN}$ is the total nitrogen and $\mathrm{F}_{\mathrm{N}}$ is the factor of 6.25 (NOGUEIRA; SOUZA, 2005).

The data were subjected to analysis of variance and mean test, with means grouped by the Scott-Knott test at 5\% probability, using SISVAR software version 5.3 (FERREIRA, 2011).

\section{RESULTS AND DISCUSSION}

According to the analysis of variance (Table 2) there was a significant container $x$ substrate interaction for the number of leaves, Conilon coffee height, root length and total nitrogen. For the other variables, there was no significant effect.

When evaluating the significant effect of the isolated factors, it was noted that only the root length and the Dickson quality index had a significant effect for the substrate factor. For the container factor, the variables had a significant effect, except for the SDM/RDM ratio.

According to Table 3, when evaluating the number of leaves, it was noted that there was no significant difference for the Cont. 1 and 2 within the substrates. However, the Cont. 3 showed significance in the substrates S1 and S2 (17.00 and 16.00 leaves, respectively), differing statistically from S3 and S4 (11.67 and 14.00 leaves, respectively). The results demonstrate the S2 potential to replace the commercial substrate for production of seedlings.

Different substrates for production of seedlings still need further studies aiming at alternative means for the producer. Dias et al. (2009) added $40 \%$ turkey litter to the conventional substrate and found favoring development of coffee seedlings, while the cow dung when added to the conventional substrate hindered the development of seedlings, regardless of its proportion.

When evaluating the effect of container on the number of leaves, it is evident that the increased volume of the same favored greater development, once the Cont. 2 and 3, tube and bag provided higher values of this variable.

Similar result was verified by Vallone et al. (2009). When evaluating different containers for production of Arabica coffee (Coffea arabica) seedlings, the authors concluded that seedlings produced in polyethylene bags $(700 \mathrm{~mL})$ and in a $120 \mathrm{~mL}$ tube, using standard substrate, were superior to the derived from seedlings produced in $50 \mathrm{~mL}$ tubes. 
TABLE 2 - Summary of the analysis of variance of the interaction between container and substrate (Cont. *Sub.), indicating the coefficients of variation $(\mathrm{CV})$, degrees of freedom $(\mathrm{GL})$ and the mean squares of response variables

\begin{tabular}{|c|c|c|c|c|c|c|}
\hline \multirow{2}{*}{ Source of variation } & \multirow{2}{*}{ GL } & \multicolumn{5}{|c|}{ Mean square } \\
\hline & & SHDM & $\mathrm{RDM}$ & NL & HGT & LA \\
\hline Container (Cont.) & 2 & $13.81^{* *}$ & $0.80^{* *}$ & $84.00^{* *}$ & $824.77^{* *}$ & $3673.39^{* *}$ \\
\hline Error 1 & 6 & 0.12 & 0.06 & 3.67 & 12.29 & 90.63 \\
\hline Substrate (Sub.) & 3 & $0.69^{\mathrm{ns}}$ & $0.10^{\mathrm{ns}}$ & $0.81^{\mathrm{ns}}$ & $41.27^{\mathrm{ns}}$ & $133.22^{\mathrm{ns}}$ \\
\hline Cont.*Sub. & 6 & $0.98^{\text {ns }}$ & $0.06^{\mathrm{ns}}$ & $12.48^{*}$ & $41.11^{*}$ & $530.51^{\mathrm{ns}}$ \\
\hline Block & 2 & $0.10^{\text {ns }}$ & $0.03^{\mathrm{ns}}$ & $4.08^{\mathrm{ns}}$ & $6.67^{\mathrm{ns}}$ & $142.60^{\mathrm{ns}}$ \\
\hline Error 2 & 16 & 0.91 & 0.22 & 4.03 & 13.61 & 403.84 \\
\hline Total & 35 & & & & & \\
\hline Overall average & & 1.92 & 0.71 & 13.67 & 22.39 & 38.00 \\
\hline CV $1(\%)$ & & 18.49 & 34.23 & 14.01 & 15.66 & 25.05 \\
\hline \multirow[t]{2}{*}{ CV $2(\%)$} & & 49.88 & 66.61 & 14.69 & 16.48 & 52.88 \\
\hline & & DQI & $\mathrm{SDM} / \mathrm{RDM}$ & $\mathrm{RS}$ & $\mathrm{TN}$ & TCP \\
\hline Container (Cont.) & 2 & $0.02^{\mathrm{ns}}$ & $6.47^{\mathrm{ns}}$ & $208.44^{* *}$ & $917.65^{* *}$ & $3689.12^{* *}$ \\
\hline Error 1 & 6 & 0.01 & 2.00 & 18.31 & 47.68 & 90.90 \\
\hline Substrate (Sub.) & 3 & $0.03^{*}$ & $0.86^{\mathrm{ns}}$ & $34.03^{*}$ & $22.71^{\mathrm{ns}}$ & $131.27^{\mathrm{ns}}$ \\
\hline Cont.*Sub. & 6 & $0.01^{\mathrm{ns}}$ & $4.16^{\mathrm{ns}}$ & $22.30^{*}$ & $156.16^{* *}$ & $527.46^{\mathrm{ns}}$ \\
\hline Block & 2 & $0.00^{\mathrm{ns}}$ & $0.11^{\mathrm{ns}}$ & $3.69^{\mathrm{ns}}$ & $9.87^{\mathrm{ns}}$ & $143.27^{\mathrm{ns}}$ \\
\hline Error2 & 16 & 0.01 & 0.27 & 6.44 & 27.87 & 403.84 \\
\hline Total & 35 & & & & & \\
\hline Overall average & & 0.19 & 2.93 & 19.19 & 24.96 & 38.19 \\
\hline CV $1(\%)$ & & 53.03 & 48.29 & 22.19 & 27.67 & 24.96 \\
\hline CV $2(\%)$ & & 45.70 & 51.51 & 13.22 & 21.15 & 52.62 \\
\hline
\end{tabular}


TABLE 3 - Number of leaves (NL) and plant height (PH) of Conilon coffee seedlings in different substrates and containers

\begin{tabular}{|c|c|c|c|c|c|c|}
\hline \multirow{2}{*}{ Substrates } & \multicolumn{3}{|c|}{ NL } & \multicolumn{3}{|c|}{ PH (cm plant $\left.{ }^{-1}\right)$} \\
\hline & Cont. 1 & Cont. 2 & Cont. 3 & Cont. 1 & Cont. 2 & Cont. 3 \\
\hline S1 & $9.67 \mathrm{Ab}$ & $14.67 \mathrm{Aa}$ & $17.00 \mathrm{Aa}$ & $11.83 \mathrm{Ac}$ & $19.83 \mathrm{Bb}$ & $34.17 \mathrm{Aa}$ \\
\hline $\mathrm{S} 2$ & $11.33 \mathrm{Ab}$ & $14.00 \mathrm{Aa}$ & $16.00 \mathrm{Aa}$ & $14.50 \mathrm{Ab}$ & $29.00 \mathrm{Aa}$ & $31.83 \mathrm{Aa}$ \\
\hline S3 & $10.67 \mathrm{Ab}$ & $17.33 \mathrm{Aa}$ & $11.67 \mathrm{Bb}$ & $12.83 \mathrm{Ab}$ & $23.50 \mathrm{Ba}$ & $24.00 \mathrm{Ba}$ \\
\hline S4 & $11.00 \mathrm{Ab}$ & $16.67 \mathrm{Aa}$ & $14.00 \mathrm{Ba}$ & $15.50 \mathrm{Ab}$ & $20.50 \mathrm{Bb}$ & $30.67 \mathrm{Aa}$ \\
\hline
\end{tabular}

S1 - Conventional; S2 - Legume + dried cow dung compost; S3 - Grass + dried cow dung compost; S4 Vermicompost. Cont. 1 - tube $\left(120 \mathrm{~cm}^{3}\right)$; Cont. 2 - tube $\left(280 \mathrm{~cm}^{3}\right)$; Cont. 3 - bag $\left(615 \mathrm{~cm}^{3}\right)$.

Averages followed by the same capital letters on the columns and lowercase on the rows belong to the same group by Scott-Knott test $(\mathrm{p} \leq 0.05)$.

For plant height, that there was no significant difference between the substrates in the Cont. 1 . In the Cont. 2, the highest average was in S2 (29 $\mathrm{cm}$ plant ${ }^{-1}$ ), differing statistically from the others. In the Cont. 3, the statistically superior averages were found in S1, S2 and S4 (34.17, 31.83 and $30.67 \mathrm{~cm} \mathrm{plant}^{-1}$, respectively). The grass + cow dung compost $(\mathrm{S} 3)$ provided lower plant height $\left(24.00 \mathrm{~cm} \mathrm{plant}^{-1}\right)$.

It is evidenced the effect of the container in the development of Conilon coffee height, once the greater averages were found in Cont. 3 , showing the highest volumetric capacity (615 $\left.\mathrm{cm}^{3}\right)$ in relation to Cont. 1 and 2 (120 and $280 \mathrm{~cm}^{3}$, respectively).

In S2 and S3, the Cont. 2 and 3 were statistically superior to Cont. 1. In S1 and S4, the highest average was obtained in Cont. 3 (34.17 and $30.67 \mathrm{~cm} \mathrm{plant}^{-1}$, respectively), differing from the others.

For Dias et al. (2009), the volumetric capacity of containers directly influence the plant development, altering their physiological development. The authors also highlight that the number of leaf pairs should be a variable to define the management of seedlings under nursery conditions and their acclimatization for field planting.

When the root length was evaluated (Table 4), it was observed that there was statistical difference only for Cont. 2 within S4, whose average was $21.17 \mathrm{~cm} \mathrm{plant}^{-1}$, differing from the others. When the effect of the container on root development was studied, it is noted that Cont. 3 presented the highest averages of this variable in the majority of treatments, following a certain tendency of root growth with increasing substrate volume.

The good root development is a key factor for the good setting of coffee seedlings in the field. According to Vallone et al. (2009), coffee seedlings produced in higher volume containers (120 and $700 \mathrm{~cm}^{3}$ ) will have superior development in the field in relation to the smaller ones $\left(50 \mathrm{~cm}^{3}\right)$.

A higher growth and distribution of the root system provides a greater absorption of water and nutrients by the plant, besides a lower susceptibility to soil water deficit, which was observed by Vallone et al. (2010) when they found that larger container volumes $\left(700 \mathrm{~cm}^{3}\right)$ favored the development of Arabica coffee plants.

For TN, the highest average was obtained in S3 within Cont. 2 (38.17\% plant $\left.^{-1}\right)$, differing from the others. However, within Cont. 1 and 3 there was no statistical difference between the used substrates.

For the effect of the container on the nitrogen content in the plant, it is clear that Cont. 3 , with higher volume, provided the highest averages in most treatments. However, within S2, such variable did not show a significant difference. It is remarkable the nutritional effect of the legume + dried cow dung compost on the development of Conilon coffee. 
TABLE 4 - Root length (RL) and total nitrogen (TN) of Conilon coffee seedlings in different substrates and containers.

\begin{tabular}{|c|c|c|c|c|c|c|}
\hline \multirow{2}{*}{ Substrates } & \multicolumn{3}{|c|}{ RL (cm) } & \multicolumn{3}{|c|}{ TN (\%) } \\
\hline & Cont. 1 & Cont. 2 & Cont. 3 & Cont. 1 & Cont. 2 & Cont. 3 \\
\hline S1 & $16.00 \mathrm{Aa}$ & $19.00 \mathrm{Ba}$ & $22.00 \mathrm{Aa}$ & $15.25 \mathrm{Ab}$ & $19.58 \mathrm{Bb}$ & $36.08 \mathrm{Aa}$ \\
\hline $\mathrm{S} 2$ & $15.83 \mathrm{Ab}$ & $27.33 \mathrm{Ba}$ & $22.83 \mathrm{Aa}$ & $19.25 \mathrm{Aa}$ & $26.75 \mathrm{Ba}$ & 26.89Aa \\
\hline $\mathrm{S} 3$ & $14.83 \mathrm{Ab}$ & $16.83 \mathrm{Bb}$ & $21.67 \mathrm{Aa}$ & $11.94 \mathrm{Ab}$ & $38.17 \mathrm{Aa}$ & $31.67 \mathrm{Aa}$ \\
\hline S4 & $11.00 \mathrm{Ab}$ & $21.17 \mathrm{Aa}$ & $21.83 \mathrm{Aa}$ & $16.58 \mathrm{Ab}$ & $19.36 \mathrm{Bb}$ & $38.00 \mathrm{Aa}$ \\
\hline
\end{tabular}

S1 - Conventional; S2 - Legume + dried cow dung compost; S3 - Grass + dried cow dung compost; S4 Vermicompost. Cont. 1 - tube $\left(120 \mathrm{~cm}^{3}\right)$; Cont. 2 - tube $\left(280 \mathrm{~cm}^{3}\right)$; Cont. 3 - bag $\left(615 \mathrm{~cm}^{3}\right)$.

Averages followed by the same capital letters on the columns and lowercase on the rows belong to the same group by Scott-Knott test $(\mathrm{p} \leq 0.05)$.

A higher nitrogen content in the plant may be associated with the higher volume of substrate explored by the root system, besides the availability of this nutrient in the compost. According to Santinato et al. (2014), the addition of nitrogen to the substrate containing cow dung is important to supply the requirement for this nutrient in the seedlings. However, the data obtained in the present study demonstrate that the substrate volume (larger containers) significantly influenced the nitrogen concentration in the plant, since the higher volumes of substrates provided higher nitrogen contents for the plant.

The shoot dry mass (Figure 1) showed higher average in Cont. 3 (2.92 g plant $\left.^{-1}\right)$, differing significantly from the others. The lowest dry mass was obtained in Cont. $1\left(0.78 \mathrm{~g} \mathrm{plant}^{-1}\right)$. Therefore, the higher substrate volume favors the production of shoot dry mass and hence the production of Conilon coffee seedlings.

When evaluating different containers and substrates, Vallone et al. (2009) observed that Arabica coffee seedlings produced in a $120 \mathrm{~mL}$ tube and a $700 \mathrm{~mL}$ bag were superior to those produced in a $50 \mathrm{~mL}$ container at 20 months after field transplantation. Thereby, the influence of substrate volume is evident both in the development stage of seedlings in the nursery and in the field.

For the root dry mass (Figure 2), it is noted that the Cont. 2 and 3 showed the highest averages $\left(0.76\right.$ and $\left.0.94 \mathrm{~g} \mathrm{plant}^{-1}\right)$, differing statistically from the Cont. 1 (0.43 $\left.\mathrm{g} \mathrm{plant}^{-1}\right)$. The root volume favors the absorption of water and nutrients by the plant, besides providing good stability, being its development essential for the success of seedling setting in the field.

In this way, the use of higher volume containers is a strategy for production of seedlings corroborated by Francisco et al. (2010) and Vallone et al. (2009). However, as the Cont. 2 was significantly equal the Cont. 3 , the smaller volume can be used aiming at the economy of substrates, decreasing the production cost of seedlings.

The leaf area (Figure 3) was significantly influenced by the container volume. It is noted that Cont. 3 provided the highest average $\left(53.61 \mathrm{~cm}^{2}\right.$ plant $^{-1}$ ), differing statistically from the others. The Cont. 1 presented the worst result (19.09 $\left.\mathrm{g} \mathrm{plant}^{-1}\right)$.

The leaf area is a response to the good root development of plant, which can be understood when comparing Figures 2 and 3. A larger leaf area will directly influence the production of photoassimilates and hence the plant development. Therefore, containers that favor the leaf area should be preferred to the detriment of those that restrict it.

According to Dias et al. (2009), the plants growing in a higher volume of substrate show higher leaf area parameters, favoring a greater amount of reserve (carbohydrate) and metabolized, thus providing quality seedlings. This result was corroborated by Dardengo et al. (2013). 


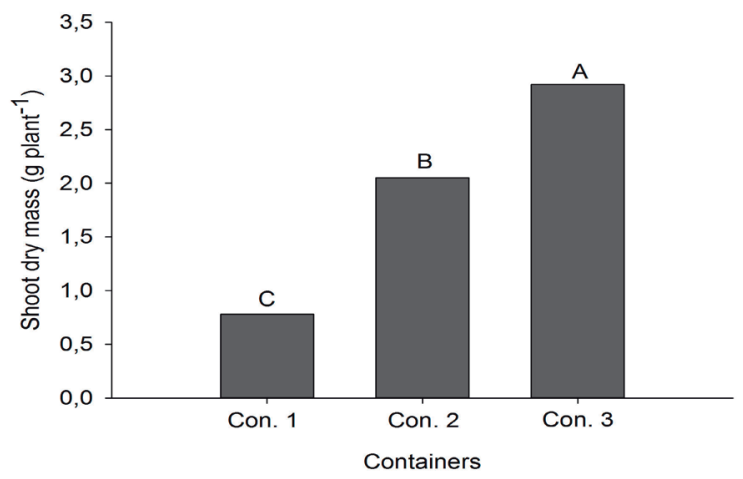

FIGURE 1 - Shoot dry mass in function of the containers. Cont. 1 - tube $\left(120 \mathrm{~cm}^{3}\right)$; Cont. 2 - tube $\left(280 \mathrm{~cm}^{3}\right)$; Cont. 3 - bag $\left(615 \mathrm{~cm}^{3}\right)$.

Averages followed by the same capital letters on the columns belong to the same group by Scott-Knott test ( $\mathrm{p} \leq 0.01)$.

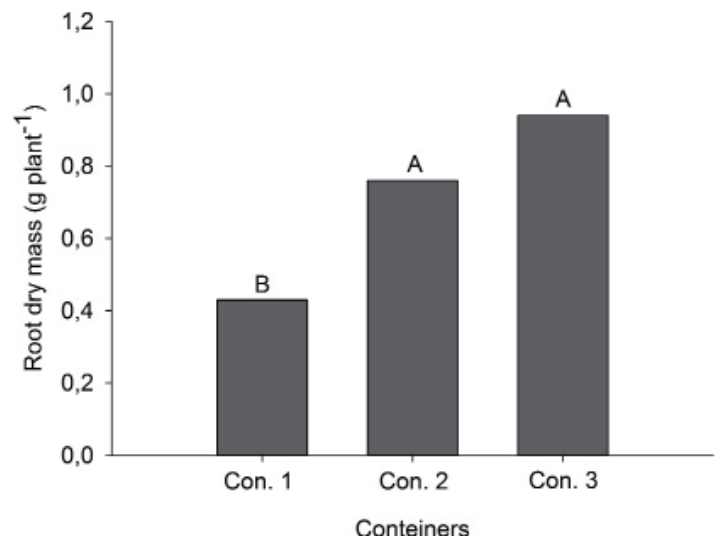

FIGURE 2 - Root dry mass in function of the containers. Con. 1 - tube $\left(120 \mathrm{~cm}^{3}\right)$; Con. 2 - tube $\left(280 \mathrm{~cm}^{3}\right)$; Con. 3 - bag $\left(615 \mathrm{~cm}^{3}\right)$.

Averages followed by the same capital letters on the columns belong to the same group by Scott-Knott test $(\mathrm{p} \leq 0.01)$.

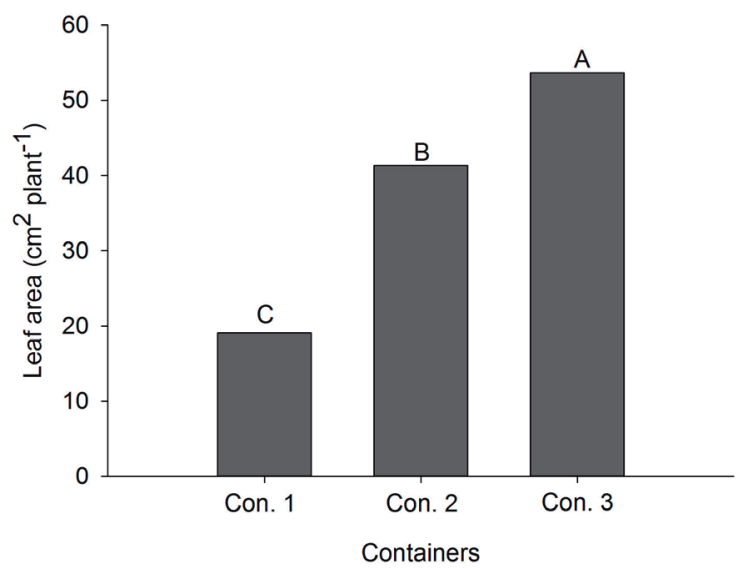

FIGURE 3 - Leaf area in function of the containers. Cont. 1 - tube $\left(120 \mathrm{~cm}^{3}\right)$; Cont. 2 - tube $\left(280 \mathrm{~cm}^{3}\right)$; Cont. 3 - bag $\left(615 \mathrm{~cm}^{3}\right)$.

Averages followed by the same capital letters on the columns belong to the same group by Scott-Knott test $(\mathrm{p} \leq 0.01)$.

Coffee Science, Lavras, v. 13, n. 1, p. 80 - 89, jan./mar. 2018 
According to Figure 4, the S2 provided the highest average for the Dickson quality index (0.26), differing statistically from the others. The lowest average was obtained in S3 (0.13). According to Marana et al. (2008), the principle of quantitative evaluation is that the bigger the seedlings, the better. However, in order to avoid distortions from excess nitrogen, e.g., or from leaf growth to the detriment of the root system, quality indexes are used as relationships among growth parameters.

When establishing the minimum value of 0.2 for the Dickson quality index (HUNT, 1990), it is observed that only S2 showed a value higher than that (0.26). For Dardengo et al. (2013), this index was efficient to indicate the quality of Conilon coffee seedlings in different containers $\left(120 \mathrm{~cm}^{3}\right.$ tube and $\left.770 \mathrm{~cm}^{3} \mathrm{bag}\right)$. The values obtained in the present study are close the mentioned by Dardengo et al. (2013).
When studying the effect of tube size on seedling quality of three forestry species, Ferraz and Engel (2011) observed that the best averages for the Dickson quality index were obtained in larger containers.

In Figure 5 is shown that Cont. 3 provided the highest average for total crude protein $(53.82 \%$ plant $\left.^{-1}\right)$, differing statistically from the others. The second best average was obtained in Cont. $2\left(41.53 \%\right.$ plant $\left.^{-1}\right)$ followed by Cont. 1 (19.23\% plant $\left.^{-1}\right)$. Thereby, it is suggested that a higher volume of substrate favors the crude protein production in Conilon coffee plants and hence their initial development.

Similarly to the total nitrogen content, the crude protein showed higher average content in Cont. 3. The nitrogen concentration in the plant is related to the protein synthesis (TAIZ; ZEIGER, 2013), as verified by Gomes Júnior and Sá (2010) in the bean crop.

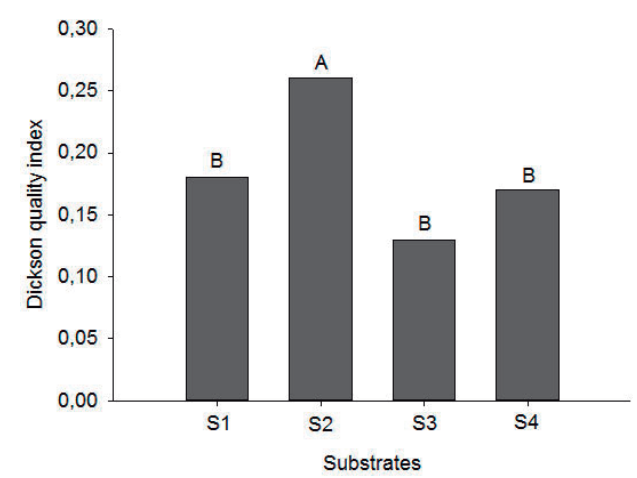

FIGURE 4 - Dickson quality index in function of the substrates. S1 - Conventional; S2 - Legume + dried cow dung compost; S3 - Grass + dried cow dung compost; S4 - Vermicompost.

Averages followed by the same capital letters on the columns belong to the same group by Scott-Knott test ( $\mathrm{p} \leq 0.05)$.

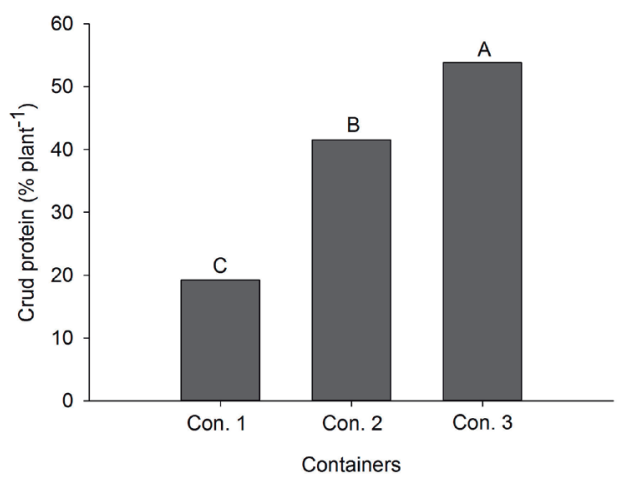

FIGURE 5 - Total crude protein in function of the containers. Cont. 1 - tube $\left(120 \mathrm{~cm}^{3}\right)$; Cont. 2 - tube $\left(280 \mathrm{~cm}^{3}\right)$; Cont. 3 - bag $\left(615 \mathrm{~cm}^{3}\right)$.

Averages followed by the same capital letters on the columns belong to the same group by Scott-Knott test ( $\mathrm{p} \leq 0.05)$. 


\section{CONCLUSIONS}

The alternative substrates (Legume compost, Grass compost and Vermicompost) were efficient for production of Conilon coffee seedlings and can replace the conventional substrate at this development stage, providing good quality seedlings.

The major developments were observed in the containers with the highest volume $\left(280 \mathrm{~cm}^{3}\right.$ tube and $615 \mathrm{~cm}^{3} \mathrm{bag}$ ) and reflected directly on the quality of seedlings.

\section{REFERENCES}

ALMEIDA S. L. S. et al. Adição de resíduos orgânicos ao substrato para produção de mudas de café em tubete. Revista Agrogeoambiental, Pouso Alegre, v. 3, n. 123, p. 9-13, 2011.

ALVES, J. D.; GUIMARÃES, R. J. Sintomas de desordens fisiológicas em cafeeiro. In: GUIMARÃES, R. J.; MENDES, A. N. G.; BALIZA, D. P. (Ed.). Semiologia do cafeeiro: sintomas de desordens nutricionais, fitossanitárias e fisiológicas. Lavras: Ed. UFLA, 2010. p. 169-215.

CALDEIRA, M. V. W. et al. Composto orgânico na produção de mudas de aroeira vermelha. Scientia Agraria, Curitiba, v. 9, n. 1, p. 27-33, 2008.

CARVALHO, G. R. et al. Normas e padrões para a comercialização de sementes e mudas de cafeeiros em Minas Gerais. Informe Agropecuário, Belo Horizonte, v. 29, n. 247 , p. 24-30, 2008.

DARDENDO, M. C. J. D. et al. Crescimento e qualidade de mudas de café conilon produzidas em diferentes recipientes e níveis de sombreamento. Coffee Science, Lavras, v. 8, n. 4, p. 500-509, 2013.

DIAS, R. et al. Fontes e proporção de material orgânico para a produção de mudas de cafeeiro em tubetes. Ciência e Agrotecnologia, Lavras, v. 33, n. 3, p. 758764, maio/jun. 2009.

DICKSON, A.; LEAF, A. L.; HOSNER, J. F. Quality appraisal of white spruce and white pine seedling stock in nurseries. Forest Chronicle, Mattawa, v. 36, p. 1013, 1960 .

FERRAZ, A. V.; ENGEL, V. L. Efeito do tamanho de tubetes na qualidade de mudas de jatobá (Hymenaea courbaril L. var. stilbocarpa (Hayne) Lee et Lang.), ipê- amarelo (Tabebuia chrysotricha (Mart. ex DC.) Sandl.) e guarucaia (Parapiptadenia rígida (Benth.) Brenan). Revista Árvore, Viçosa, v. 35, n. 3, p. 413-423, 2011.

FERREIRA, D. F. Sisvar: a computer statistical analysis system. Ciência e Agrotecnologia, Lavras, v. 35, n. 6, p. 1039-1042, nov./dez. 2011.

FRANCISCO, G. S. et al. Substratos e recipientes na produção de mudas de mamoeiro 'Sunrise Solo'. Revista Agrarian, Dourados, v. 3, n. 9, p. 267-274, 2010.

GOMES JÚNIOR, F. G.; SÁ, M. E. de. Proteína e qualidade de sementes de feijão (Phaseolus vulgaris L.) em função da adubação nitrogenada em plantio direto. Revista Brasileira de Sementes, Londrina, v. 32, n. 1, p. 34-44, 2010.

HENRIQUE, P. C. et al. Aspectos fisiológicos do desenvolvimento de mudas de café cultivadas sob telas de diferentes colorações. Pesquisa Agropecuária Brasileira, Brasília, DF, v. 46, n. 5, p. 458-465, maio 2011.

HUNT, G. A. Effect of styroblock design and cooper treatment on morphology of conifer seedlings. In: TARGET SEEDLING SYMPOSIUM, MEETING OF THE WESTERN FOREST NURSERY ASSOCIATIONS, GENERAL TECHNICHAL REPORT RM-200, 1990, Roseburg. Proceedings... Fort Collins: United States Department of Agriculture, Forest Service, 1990. p. 218-222.

MARANA, J. B. et al. Índices de qualidade e crescimento de mudas de café produzidas em tubetes. Ciência Rural, Santa Maria, v. 38, n. 1, p. 39-45, 2008.

MATIELlO, J. B. et al. Cultura do café no Brasil: novo manual de recomendações. Varginha: PROCAFÉ, $2005.438 \mathrm{p}$.

NOGUEIRA, A. R. A.; SOUZA, G. B. Manual de laboratórios: solo, água, nutrição vegetal, nutrição animal e alimentos. São Carlos: EMBRAPA Pecuária Sudeste, 2005. $313 \mathrm{p}$.

PARTELLI, F. L. et al. Estimativa da área foliar do cafeeiro conilon a partir do comprimento da folha. Revista Ceres, Viçosa, v. 53, n. 306, p. 204-210, 2006.

PREZOTTI, L. C. et al. Manual de recomendação de calagem e adubação para o Estado do Espírito Santo: $5^{\mathrm{a}}$ aproximação. Vitória: SEEA/Incaper/ Cedagro, 2007. 305 p. 
SANTINATO, F. et al. Doses of phosphorus associated with nitrogen on development of coffee seedlings. Coffee Science, Lavras, v. 9, n. 3, p. 419-426, 2014.

SILVA, J. I. et al. Desenvolvimento de mudas de Coffea canephora PIERRE ex A. FROEHNER em diferentes combinações de substrato e recipiente. Coffee Science, Lavras, v. 5, n. 1, p. 38-48, 2010.

SOUZA, M. P. S. et al. A valorização do lixo orgânico no setor de agroecologia no Instituto Federal do Espírito Santo Campus de Alegre. Cadernos de Agroecologia, Porto Alegre, v. 8, p. 1-4, 2013.

TAIZ, L.; ZEIGER, E. Fisiologia vegetal. 5. ed. Porto Alegre: Artmed, 2013. 954 p.
TRAZZI, P. A. et al. Substratos de origem orgânica para produção de mudas de teca (Tectona grandis Linn. F.). Ciência Florestal, Santa Maria, v. 23, p. 401-409, 2013.

VALLONE, H. S. et al. Efeito de recipientes e substratos utilizados na produção de mudas de cafeeiro no desenvolvimento inicial em casa de vegetação, sob estresse hídrico. Ciência e Agrotecnologia, Lavras, v. 34, n. 2, p. 320-328, mar./abr. 2010.

Recipientes e substratos na produção de mudas e no desenvolvimento inicial de cafeeiros após o plantio. Ciência e Agrotecnologia, Lavras, v. 33, n. 5, p. 1327-1335, set./out. 2009.

VALLONE, H. S.; GUIMARÃES, R. J.; MENDES, A. N. G. Diferentes recipientes e substrato na produção de mudas de cafeeiros. Ciência e Agrotecnologia, Lavras, v. 34, n. 1, p. 55-60, jan./fev. 2010. 